\title{
Bali mendongeng: Revitalisasi kearifan lokal yang memudar
}

\author{
Riza Wulandari *, I Wayan Gede Lamopia \\ Institut Teknologi dan Bisnis STIKOM Bali. Jalan Raya Puputan No.86, Denpasar, Bali 80234, Indonesia \\ * Corresponding Author. Email: rizawulandari26@gmail.com \\ Received: 1 February 2019; Revised: 12 March 2019; Accepted: 4 April 2019
}

\begin{abstract}
Abstrak
Kehidupan anak era milenial kini menjadi lebih ironi, dukungan dari sajian media yang menawarkan sisi dunia kekinian menyebabkan generasi penerus bangsa luntur nilai-nilai kearifan lokal yang telah ada pada masa lampau. Tujuan dari kegiatan pemberdayaan masyarakat pada target sasaran kelompok ibu-ibu rumah tangga Desa Manukaya adalah untuk memberikan edukasi kepada keluarga khususnya ibu yang memiliki peran penting di keluarga dalam mengantisipasi sikap negative dari dampak modernisasi. Focus Group Discussion dipilih dalam memecahkan masalah yang terjadi. Hasil dari kegiatan ini adalah tim pelaksana memberikan 2 kegiatan diantaranya adalah pertama memberikan edukasi tentang pentingnya kearifan lokal dan strategi mempertahankan kearifan lokal melalui mendongeng. Kedua memberikan pendampingan pelatihan sesuai dengan potensi yang dimiliki oleh kelompok ibuibu rumah tangga Desa Manukaya yaitu merajut. Dari potensi tersebut, diberikan kegiatan pendampingan pembuatan media boneka jari dengan cara merajut dan berbahan dasar flannel. Dari media boneka jari yang telah dibuat, diharapkan dapat diaplikasikan kepada anak-anak dalam mengajarkan kearifan lokal Bali melalui dongeng.
\end{abstract}

Kata Kunci: revitalisasi kearifan lokal, Bali mendongeng, Desa Manukaya

\section{Bali Mendongeng: Revitalization of fading local wisdom}

\begin{abstract}
The lives of the millennial era is now becoming more irony, the support of the media which offers dishes of the world side of the present generation successor Nations smudging local wisdom values that already exist in the past. The purpose of the community empowerment activities on the target objectives of the mother-homemaker village of Manukaya is to provide education to their families especially mothers who have an important role in the family in anticipation of a negative attitude from the impact the modernization. Focus Group Discussion on select in solving the case. The result of this activity is the implementing team provide activities such as the first two provide education about the importance of local wisdom and strategy of maintaining local wisdom through storytelling. Both provide a mentoring training in accordance with the potential that is owned by a group of mothers of households of the village of Manukaya that is knitting. From the potential, given the activities of accompaniment the creation of finger puppets knit and way made from flannel. From finger puppets that have been made, is expected to be applied to children of Bali's local wisdom in teaching through storytelling.
\end{abstract}

Keywords: revitalizing local wisdom, Balinese storytelling, Village Manukaya

How to Cite: Wulandari, R., \& Lamopia, I. (2019). Bali mendongeng: Revitalisasi kearifan lokal yang memudar. JPPM (Jurnal Pendidikan dan Pemberdayaan Masyarakat), 6(1), 41-49. doi:https://doi.org/10.21831/jppm.v6i1.23417

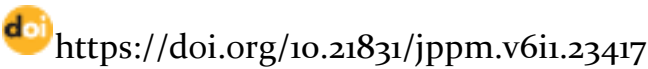

\section{PENDAHULUAN}

Di era modern saat ini, kearifan lokal seolah sudah mengalami pergeseran makna dan simbolisasi (Saddhono, 2016). Pergeseran tersebut salah satunya disebabkan oleh lunturnya nilai-nilai penanaman kearifan lokal yang dimiliki oleh suatu daerah akibat dunia digitalisasi yang merambah ke dunia generasi muda mulai dari anak-anak hingga dewasa. Teknologi yang berkembang begitu pesat dan canggihnya juga menyebabkan pola komunikasi masyarakat berubah dengan cepat (Kurmia, 2005). Pengetahuan dan peng- 


\section{JPPM (Jurnal Pendidikan dan Pemberdayaan Masyarakat), 6 (1), 2019 - 42 Riza Wulandari, I Wayan Gede Lamopia}

alaman manusia dibentuk oleh berbagai informasi yang dapat disimpan dan ditransmisikan dengan kecepatan yang begitu dahsyat dan dapat menjangkau kawasan yang begitu luas. Bahasa lisan digantikan peranannya oleh citra-citra visual. Sikap utilitarian, materialis, dan hedonis mengedepan berbarengan dengan munculnya pergeseran yang terus-menerus. Akibatnya, pandangan dunia masyarakat pun pecah, tercabik, dan salahtempat (dislokasi). Ini semua bisa diperhitungkan sebagai tantangan sekaligus ancaman bagi nilai-nilai, karakter, dan identitas bangsa.

Kearifan lokal yang berkembang di masyarakat pedesaan merupakan hasil dari kebiasaaan masyarakat setempat atau kebudayaan masyarakat sebagai bentuk adaptasi terhadap alam dan lingkungan tempat tinggalnya. Masyarakat menggunakan caracara tersendiri untuk mengelola alam dan lingkungan. Kebiasaan-kebiasaaan itu kemudian membentuk dengan apa yang disebut dengan kearifan lokal. Kearifan lokal mengandung nilai, kepercayaan, dan sistem religi yang dianut masyarakat setempat. Kearifan lokal pada intinya kegiatan yang melindungi dan melestarikan alam dan lingkungan. Oleh karena itu, penting untuk mengkaji dan melestarikan kearifan lokal yang berkembang di masyarakat. Namun seiring berjalannya waktu keberadaan kearifan lokal semakin tersingkirkan dengan masuknya berbagai teknologi dan berbagai masalah sosial yang dihadapi masyarakat seperti pertambahan penduduk yang semakin meningkat. Keadaan demikian membuat masyarakat meninggalkan kearifan lokal yang telah diturunkan secara turun-temurun. Pola pikir masyarakat mulai berubah seiring dengan memudarnya kearifan lokal yakni dari pola pikir holistik ke pola pikir mekanik. Masyarakat tidak lagi memikirkan keseimbangan alam dan lingkungan dalam mengelola sumberdaya alam dan lingkungan. Prospek kearifan lokal sangat bergantung kepada bagaimana masyarakat melestarikan kembali kearifan lokal yang ada dan bagaimana masyarakat mengubah pola pikirnya kembali ke pola pikir holistik. Sehingga sumberdaya alam dan lingkungan alam yang dimiliki masyarakat dapat dimanfaatkan dan diles- tarikan dengan tanpa menganggu keseimbangannya.

Salah satu upaya untuk melestarikan kearifan lokal dan mempertahankan kebudayaan di Indonesia adalah dengan cara melakukan transfer knowledge melalui pemberdayaan masyarakat dengan cara menumbuhkan rasa cinta akan kearifan lokal sejak dini, menciptakan lapangan pekerjaan dengan berlandaskan kearifan lokal, memberikan ruang budaya yang bisa mengapresiasikan kearifan lokal itu sendiri dan kegiatankegiatan positif dalam rangka menguatkan kearifan lokal di lingkungan sekitar.

Penguatan kearifan lokal melalui pemberdayaan juga memerlukan peran serta masyarakat dalam menciptakan kesuksesan dari kegiatan tersebut. Pada dasarnya pemberdayaan memberikan tekanan pada otonom pengambilan keputusan dari suatu kelompok masyarakat. Penerapan aspek demokrasi dan partisipasi dengan titik fokus pada lokalitas akan menjadi landasan bagi upaya penguatan potensi lokal. Pada aras ini pemberdayaan masyarakat juga difokuskan pada penguatan individu anggota masyarakat beserta pranata-pranatanya. Pendekatan utama dalam konsep pemberdayaan ini adalah menempatkan masyarakat tidak sekedar sebagai objek melainkan juga sebagai subjek Konteks pemberdayaan, sebenarnya terkandung unsur partisipasi yaitu bagaimana masyarakat dilibatkan dalam proses pembangunan, dan hak untuk menikmati hasil pembangunan. Pemberdayaan mementingkan adanya pengakuan subjek akan 16 kemampuan atau daya (power) yang dimiliki objek. Secara garis besar, proses ini melihat pentingnya proses ini melihat pentingnya mengalihfungsikan individu yang tadinya objek menjadi subjek (Suyatno, 2003, p. 44). Tujuan yang ingin dicapai dari pemberdayaan adalah untuk membentuk individu dan masyarakat menjadi mandiri. Kemandirian tersebut meliputi kemandirian berpikir, bertindak dan mengendalikan apa yang mereka lakukan tersebut. Kemandirian masyarakat adalah merupakan suatu kondisi yang dialami masyarakat yang ditandai oleh kemampuan untuk memikirkan, memutuskan serta melakukan sesuatu yang dipandang tepat demi mencapai pemecahan masalah-masalah 


\section{JPPM (Jurnal Pendidikan dan Pemberdayaan Masyarakat), 6 (1), 2019 - 43 Riza Wulandari, I Wayan Gede Lamopia}

yang dihadapi dengan mempergunakan daya dan kemampuan yang terdiri atas kemampuan kognitif, konatif, psikomotorik, dengan pengerahan sumber daya yang dimiliki oleh lingkungan internal masyarakat tersebut, dengan demikian untuk menuju mandiri perlu dukungan kemampuan berupa sumber daya manusia yang utuh dengan kondisi kognitif, konatif, psikomotorik dan afektif, dan sumber daya lainnya yang bersifat fisikmaterial.

Pemberdayan masyarakat hendaklah mengarah pada pada pembentukan kognitif masyarakat yang lebih baik. Kondisi kognitif pada hakikatnya merupakan kemampuan berpikir yang dilandasi oleh pengetahuan dan wawasan seorang atau masyarakat dalam rangka mencari solusi atas permasalahan yang dihadapi. Kondisi konatif merupakan suatu sikap perilaku masyarakat yang terbentuk yang diarahkan pada perilaku yang sensitif terhadap nilai-nilai pembangunan dan pemberdayaan. Kondisi afektif adalah merupakan sense yang dimiliki oleh masyarakat yang diharapkan dapat diintervensi untuk mencapai keberdayaan dalam sikap dan perilaku. Kemampuan psikomotorik merupakan kecakapan ketrampilan yang dimiliki masyarakat sebagai upaya pendukung masyarakat dalam rangka melakukan aktivitas pembangunan. Terjadinya keberdayaan pada empat aspek tersebut (kognitif, konatif, afektif dan psikomotorik) akan dapat memberikan kontribusi pada terciptanya kemandirian masyarakat yang dicita-citakan, karena dengan demikian dalam masyarakat akan terjadi kecukupan wawasan yang dilengkapi dengan kecakapan ketrampilan yang memadai, diperkuat oleh rasa memerlukan pembangunan dan perilaku sadar akan kebutuhannya tersebut, untuk mencapai kemandirian masyarakat diperlukan sebuah proses. Melalui proses belajar maka masyarakat secara bertahap akan memperoleh kemampuan/ daya dari waktu ke-18 waktu, dengan demikian akan terakumulasi kemampuan yang memadai untuk mengantarkan kemandirian mereka, apa yang diharapkan dari pemberdayaan yang merupakan visualisasi dari pembangunan sosial ini diharapkan dapat mewujudkan komunitas yang baik dan masyarakat yang ideal (Sulistiyani, 2004, pp. 8o-81). Pemberdayaan melalui suatu masa proses belajar hingga mencapai status mandiri, meskipun demikian dalam rangka mencapai kemandirian tersebut tetap dilakukan pemeliharaan semangat, kondisi dan kemampuan secara terus menerus supaya tidak mengalami kemunduran lagi.

Dalam rangka melakukan kegiatan pemberdayaan masyarakat, peran serta masyarakat dalam pembangunan (pedesaan) merupakan aktualisasi dari kesediaan atau kemampuan anggota masyarakat untuk berkorban dan berkontribusi dalam implementasi program/proyek yang dilaksanakan. Peningkatan partisipasi masyarakat merupakan salah satu bentuk pemberdayaan masyarakat (social empowerment) secara aktif yang berorientasi pada pencapaian hasil pembangunan yang dilakukan dalam masyarakat (pedesaan) (Adisasmita, 2006, p. 35). Berkaitan dengan kearifan lokal, Bali merupakan salah satu pulau yang memiliki kompleksitas kebudayaan dan kearifan lokal di berbagai daerah. Peningkatan pengetahuan serta refleksi atas peningkatan tersebut harus disebarluaskan pada masyarakat yang ada di Bali. Salah satu sasaran yang akan melaksanakan kegiatan pemberdayaan masyarakat ini adalah kelompok ibu rumah tangga Desa Manukaya, Kecamatan Tampak Siring Kabupaten Gianyar. Keterlibatan wanita khususnya ibu rumah tangga dalam meningkatkan pengetahuan tentang kearifan lokal dan juga sebagai contoh bagi putra-putri mereka sebagai generasi penerus bangsa.

Desa manukaya terletak di kecamatan Tampak Siring Kabupaten Gianyar. Desa ini memiliki jumlah penduduk 492.757. Penduduk yang ada di Desa Manukaya masih tergolong memiliki sikap tradisional. Sebagain besar wanita yang ada di Desa Manukaya bekerja sebagai ibu rumah tangga. Jumlah kelompok ibu rumah tangga Manukaya yang akan diberikan kegiatan pemberdayaan masyarakat ini berjumlah 20 orang. (BPS, 2017) Melihat semakin bergejolak kehidupan saat ini karena pengaruh modernisasi, perlu diadakan suatu kegiatan pembedayaan masyarakat untuk memperkuat kearifan lokal yang ada di Bali. Tujuan sasaran pemberdayaan masyarakat adalah kelompok ibu rumah tangga dengan harapan dapat merefleksikan 


\section{JPPM (Jurnal Pendidikan dan Pemberdayaan Masyarakat), 6 (1), 2019 - 44 Riza Wulandari, I Wayan Gede Lamopia}

hasil dari pemberdayaan tersebut kepada anak-anaknya di rumah. Jika generasi muda terus diberikan bekal untuk mempertahankan kearifan lokal di Indonesia khususnya Bali, maka kebudayaan tersebut tidak akan punah dilahap oleh teknologi dan modernisasi. Kegiatan pemberdayaan masyarakat pada sasaran kelompok ibu-ibu rumah tangga di Desa Manukaya ini dibantu oleh fasilitator dari komunitas Bali Mendongeng. Bali Mendongeng merupakan suatu komunitas relawan dongeng yang berusaha menyebarluaskan dongeng-dongeng Bali kepada anakanak, para remaja, bahkan dewasa. Tujuan mereka menyebarluaskan budaya dongeng adalah agar eksistensi kearifan lokal salah satunya cerita dongeng Bali masih tetap terjaga dan kehidupan para generasi muda khususnya anak-anak masih tetap pada dunia bermain, berimajinasi bukan seperti yang saat ini banyak ditemukan bahwa generasi muda saat ini sudah mulai terkontaminasi oleh budaya barat dan teknologi yang semakin canggih sehingga berdampak pada sikap dewasa dini sebelum waktunya tiba. Studi penelitian yang dilakukan oleh Sukarno Budi Utomo menyimpulkan bahwa mendongeng suatu tindakan atau cara yang bijak dan cerdas untuk mendidik dan menasehati anak. Dongeng dapat memberikan efek pemuasan terhadap kebutuhan akan imajinasi dan fantasi anak. Teknik pengajaran dengan cara mendongeng memberikan dampak dalam kepemilikan sikap-sikap positif seperti berpikir kritis, memiliki rasa tanggung jawab, lebih waspada terhadap praktek pembelajarannya sendiri. Mendongeng mampu menjadikan guru lebih professional, berwawasan luas dan mampu memberi kontribusi terhadap perkembangan ilmu pengetahuan dalam dunia pendidikan. (Utomo, 2013). Penelitian lain juga menguatkan bahwa dengan cara mendongeng bisa menguatkan pendidikan karakter seorang anak. dongeng sebagai media dalam penanaman karakter sangatlah efektif untuk diterapkan kepada anak usia dini dan perlunya pembiasaan serta contoh yang baik untuk menumbuhkan karakter dari anak.(Fitroh \& Sari, 2015)

\section{METODE}

Pelaksanaan kegiatan pemberdayaan masyarakat ini tidak terlepas dari tinjauan ilmiah dengan menggunakan metode kualitatif deskriptif. Target sasaran pada kegiatan ini adalah kelompok ibu-ibu rumah tangga Desa Manukaya yang nantinya bisa memberikan transfer knowledge bagi para generasi muda khususnya anak-anak mereka. Pengumpulan data dalam kegiatan ini menggunakan observasi, wawancara dan dokumentasi. Pada proses wawancara, dilakukan dengan cara focus group discussion dan menghadirkan kelompok ibu-ibu rumah tangga Desa Manukaya dan fasilitator dari Bali Mendongeng.

Focus group discussion dalam hal ini dilakukan dengan tim peneliti, bali mendongeng dan kelompok ibu rumah tangga Desa Manukaya. Tujuan pemilihan wawancara dengan focus group discussion adalah agar mempermudah dalam menemukan permasalahan yang terjadi disana. Selain mempermudah menemukan masalah, teknik ini dirasa cukup efisien dalam pemilihan waktu dan tempat. Kegiatan ini dilaksanakan di rumah Ibu Peri salah satu kelompok IbuIbu rumah tangga Desa Manukaya. Ibu Peri bisa disebut sebagai pencetus kelompok ini. Pada dasarnya, kelompok ibu rumah tangga ini memiliki potensi keahlian yakni merajut. Kegiatan mereka sehari-hari selain menjadi ibu rumah tangga adalah pada saat berkumpul mereka merajut sederhana di rumah Ibu Peri.

\section{HASIL DAN PEMBAHASAN}

Indonesia merupakan Negara nusantara yang dipenuhi dengan adat istiadat, identitas budaya yang sangat menarik. Identitas atau kepribadian budaya yang dimiliki oleh suatu bangsa sehingga menyebabkan bangsa tersebut mampu menyerap dan mengaplikasikan dalam kehidupan sehari hari disebut sebagai kearifan lokal (Wibowo, 2015). Kearidan lokal menjadi salah satu saran dalam mengolah kebudayaan dan mempertahankan jati diri bangsa dari kebudayaan asing yang tidak baik. Quaritch Wales mengemukakan pendapatnya tentang kearifan lokal sebagai dalam kearifan lokal 


\section{JPPM (Jurnal Pendidikan dan Pemberdayaan Masyarakat), 6 (1), 2019 - 45 Riza Wulandari, I Wayan Gede Lamopia}

terdapat karakter budaya, kelompok pemiliki budaya dan pengalaman hidup yang lahir dari karakter budaya (Antosa, 2014; Ramadhan, 2015; Sutarman, 2017).

Pada dasarnya tujuan dari kearifan lokal adalah sebagai peningkatan kesejahteraan dan menciptakan kedamaian bagi suatu bangsa (Sibarani, 2012). Produk kultural yang ada pada kearifan lokal menjadi suatu sistem nilai, kepercayaan,agama.etos kerja bahkan pola dinamika itu berlangsung. Kenyataan konseptual yang mengatakan kearifan lokal merupakan alat pemersatu dan penguat jati diri bangsa memang benar, namun ironi yang saat ini terjadi para generasi muda adalah kearifan lokal sudah mulai luntur.

Kelompok Ibu-ibu rumah tangga Desa Manukaya adalah salah satu mitra dalam kegiatan pengabdian masyarakat ini. Pemberdayaan masyarakat diberikan kepada mereka dengan harapan setelah adanya sosialisasi ini mereka mampu memberdayakan diri secara mandiri dan mengimplementasikan kepada anak-anak. Pada kunjungan pertama yang dilakukan oleh tim pelaksana dari STMIK STIKOM Bali adalah diadakan Focus Group Discussion untuk menemukan permasalahan yang mereka alami terkait dengan bidang sosial. Pada diskusi tersebut, tim pelaksana menemukan permasalahan yakni adanya kebudayaan asing yang masuk, siaran televise yang dirasa sudah jarang terkait pengetahuan anak-anak menyebabkan mereka sulit berkomunikasi dengan baik secara sopan dengan orang tua. Anak-anak era saat ini lebih memilih untuk hidup di layar ponsel mereka daripada kembali ke dunia anak-anak seperti bermain, belajar, dan berbakti kepada orang tua. Dari adanya hal itu, maka tim pelaksana mencoba untuk menggugah kembali semangat kearifan lokal yang ternyata para ibu ibu rumah tangga Desa Manukaya tidak mengetahui urgensi dari kearifan lokal dan strategi mempertahankannya.

Berkaitan dengan potensi yang bisa digali pada Desa Manukaya, kelompok ibuibu rumah tangga di sana mahir dalam merajut. Selama ini kegiatan mingguan yang mereka lakukan adalah salah satunya membuat tas dan membuat alas gelas. Hasil rajutan tersebut ditawarkan pada wisatawan asing yang berkunjung ke Desa Manukaya untuk melakukan aktivitas cycling. Potensi merajut yang dijadikan sebagai usaha sampingan ini sebenarnya bisa dijadikan sebagai sebuah kekuatan diri untuk menjadi mandiri jika dikelola dengan baik dan terstruktur.

Dalam kegiatan ini dibagi menjadi dua tahap yakni memberikan edukasi kepada Ibuibu Rumah Tangga Desa Manukaya tentang pentingnya mempertahankan kearifan lokal dan juga pendampingan pelatihan untuk membuat boneka jari sebagai media mendongeng. Teras rumah milik Ibu Peri digunakan sebagai ruang publik bagi masyarakat Desa Manukaya. Dengan ruang publik yang tidak begitu luas dan terbuka, tidak menghalangi mereka dalam berinteraksi sosial, melakukan kegiatan sosial.

Kegiatan pertama adalah pemberian edukasi tentang pentingnya mengenal kearifan lokal dan mempertahankan kearifan lokal. Edukasi ini dilaksanakan di ruang publis teras Ibu Peri. Melalui focus group discussion, kegiatan ini dimulai dengan memberikan pengetahuan tentang kearifan lokal. Materi yang diberikan berupa ceramah dan pemberian draft materi kepada ibu-ibu. Pemberian edukasi melalui pengetahuan ini tidak menggunakan media seperti layar OHP dan Proyektor karena minimnya listrik di rumah Ibu Peri hingga akhirnya sepakat hanya berupa ceramah. Penting bahwa masyarakat saat ini mengetahui makna dari kearifan lokal sehingga dalam menghadapi tantangan global dan dunia yang semakin modern ini, kearifan lokal yang berasal dari kumpulan tradisi, adat istiadat, budaya masih tetap terjaga. Penyebaran edukasi tentang urgensi kearifan lokal ini harus diberikan pada segala lapisan masyarakat. Hal itu dikarenakan aktor dari dunia ini adalah masyarakat, mereka yang mendapatkan mereka pula yang menjalankan tinggal bagaimana arah yang akan diberlakukan.

Selain memberikan edukasi tentang pentingnya kearifan lokal melalui ceramah dari konsep-konsep ilmiah, tim pelaksana juga memaparkan strategi dalam mempertahankan kearifan lokal melalui mendongeng. Saat ini, mendongeng sudah jarang kita temui dalam kehidupan sehari-hari akibat siaran media sosial seperti youtube atau media elektronik seperti televisi yang menyajikan 


\section{JPPM (Jurnal Pendidikan dan Pemberdayaan Masyarakat), 6 (1), 2019 - 46 Riza Wulandari, I Wayan Gede Lamopia}

kehidupan dunia modern. Beberapa tayangan yang ditampilkan di media sosial ataupun elektronik terkadang tidak mampu menyaring hal yang baik untuk usia anak.

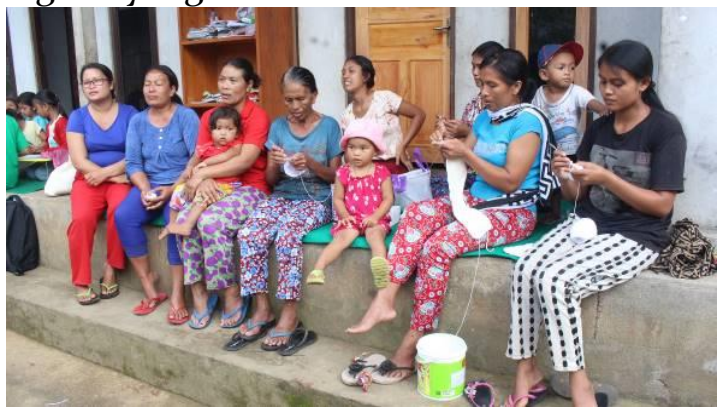

Gambar 1. Sebagaian dari Kelompok Ibu Manukaya

Strategi mempertahankan kearifan lokal di Bali khususnya dengan cara mendongeng ini difasilitasi oleh komunitas Bali Mendongeng. Komunitas ini memiliki tujuan menyebarkan budaya dongeng Bali dengan menggunakan media boneka jari. Tim pelaksana dan komunitas Bali Mendongeng berkolaborasi memberikan edukasi tentang cara mendongeng menggunakan media boneka jari. Peserta pemberdayaan masyarakat pada kelompok ibu-ibu rumah tangga Desa Manukaya sangat antusias mengikuti pemberdayaan ini. Salah satu ibu rumah tangga bernama Ibu Wayan juga menyampaikan kegelisahan hatinya tentang anak-anak sekarang sudah tidak seperti anak jaman dulu yang kehidupannya bermain, bercerita sesuai dengan usia mereka. bahkan anak-anak sekarang sudah tidak mengenal cerita dongeng. Keluhan tersebut menjadikan tim pelaksana dan komunitas Bali Mendongeng semangat untuk memberikan edukasi tentang cara mendongeng salah satunya menggunakan boneka jari.

Beberapa teori dijelaskan oleh komunitas Bali Mendongeng seperti teknik mendongeng, jenis media mendongeng, teknik mendongeng menggunakan media tangan/ jari. Diawali dengan penjelasan teknik mendongeng, pada teknik mendongeng ini peserta diberikan pengetahuan ada dua jenis teknik mendongeng yaitu mendongeng atau bercerita menggunakan alat peraga dan dan tanpa alat peraga. Pada kegiatan ini, fasilitator memberikan edukasi teknik mendongeng dengan menggunakan alat peraga.
Mendongeng atau bercerita dengan menggunakan alat peraga dapat dikategorikan menjadi dua yaitu alat peraga langsung dan tidak langsung. Pada Alat peraga langsung seperti binatang atau benda yang sebenarnya. Alat peraga tidak langsung seperti benda-benda tiruan, gambar-gambar, guntingan-guntingan gambar yang ditempel pada flanel, membacakan cerita dan sandiwara boneka. Boneka adalah salah satu alat yang paling populer dalam melakukan kegiatan mendongeng. Berbagai macam karakter yang bisa dimunculkan seperti kelinci, kucing, dan bahkan manusia. Warna yang menarik membuat dongeng semakin menarik. Alat peraga yang digunakan berbagai macam salah satunya boneka jari. Teknis menggunakan boneka jari ini diselipkan di jari dan tinggal digerakkan. Kelemahannya bentuk boneka jari biasanya kecil dan sulit dilihat oleh anak yang duduk paling belakang bila pendengar dongeng jumlahnya banyak. Teknik mendongeng menggunakan boneka jari adalah (1) Jarak boneka tidak terlalu dekat dengan mulut pencerita. (2) Kedua tangan harus lentur memainkan boneka. (3) Antara gerakan boneka dengan tangan suara tokoh harus sinkron. (4) Sedapat mungkin, selipkan nyanyian dalam cerita melalui perilaku tokoh. (5) Selipkan beberapa pernyataan non-cerita sebagai pengisi cerita, sekaligus pelibatan anak. (6) Lakukan improvisasi melalui tokoh dengan melakukan interaksi langsung dengan anak. (7) Tutup cerita dengan membuat simpulan dan ajukan pertanyaan cerita yang berfungsi sebagai latihan bagi anak. Teknik tersebut bisa digunakan pada saat ibu memberikan dongeng untuk anak-anaknya dirumah sebagai penghantar tidur, mengisi waktu luang saat libur atau hal lainnya.

Pada kegiatan berikutnya, tim pelaksana dan fasilitator telah mempersiapkan dongeng yang akan diberikan kepada anakanak kelompok ibu rumah tangga Desa Manukaya. Salah satu dongeng yang akan diberikan pada kegiatan pengabdian masyarakat ini adalah dongeng Siap Selem. Dongeng Siap Selem ini berceritakan tentang seekor ayam betina yang memiliki anak sejumlah 11 dan seekor musang. Pola mendongeng yang diberikan kepada kelompok ibuibu rumah tangga Desa Manukaya dengan 
menggunakan media yang lebih modern yakni boneka jari. Sebelum masuk ke dongeng Siap Selem, tim pelaksana dan komunitas Bali Mendongeng memberikan materi tentang teknik mendongeng menggunakan boneka tangan dan jari.

Dalam hal ini, anak-anak diikutsertakan dalam melakukan dongeng Siap Selem. Kegiatan mendongeng ini diberikan kepada komunitas Bali Mendongeng dan hal ini sangat memberikan kesan positif bagi para kelompok ibu-ibu rumah tangga. Dongeng Siap Selem ini menceritakan tentang kisah ayam dan musang. Singkat cerita ayam dan anak-anak yang sedang berteduh di rumah musang, tiba-tiba mendapatkan firasat bahwa musang akan memangsa semua anakanak ayam. Dengan usaha dan kegigihan Induk Ayam melindungi anak-anaknya, akhirnya musang gagal memangsa anak-anak dari Siap Selem. Makna dari dongeng Siap Selem ini adalah tentang kecerdasan bisa melawan niat jahat seseorang, kepamrihan seekor musang yang mau menolong hanya karena ingin memangsa anak ayam. Dongeng siap selem ini juga menginsipirasi bahwa kasih saying seorang ibu kepada anakanaknya apapun akan dilakukan.

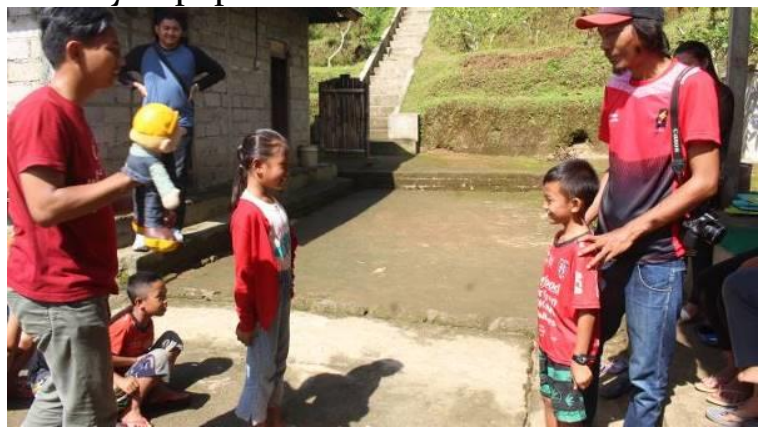

Gambar 2. Dongeng Siap Selem

Dongeng Siap Selem ini diberikan dengan menggunakan bahasa Bali. Secara tidak langsung, bahasa Bali dan cerita dari dongeng tersebut terus terjaga dan lestari di dunia anak-anak. Mendongeng dengan cara boneka jari/tangan ini merupakan sebuah inovasi dari teknik mendongeng agar anak tidak merasa bosan hanya dengan membaca dari buku namun juga bisa mempraktekkan sendiri dengan teman-teman sekitar. Setelah memberikan satu contoh mempertahankan kearifan lokal dengan mendongeng khas Bali. Tim pelaksana beralih kepada Ibu-ibu Rumah
Tangga Desa Manukaya dengan memberikan pelatihan dan pendampingan pembuatan boneka jari dengan menggunakan bahan flannel dan bahan merajut. Bahan flannel ini dipilih karena tingkat pembuatan boneka cukup mudah. Selain flannel, pelatihan membuat boneka jari menggunakan bahan benang rajut. Hal ini dikarenakan melihat potensi dari ibu-ibu yang ada di Desa Manukaya yaitu merajut. Tim pelaksana dan Bali Mendongeng memberikan arahan kepada kelompok Ibu-ibu Rumah Tangga Desa Manukaya untuk membuat boneka berbahan flannel dan bahan rajut ini tema Dongeng Siap Selem.

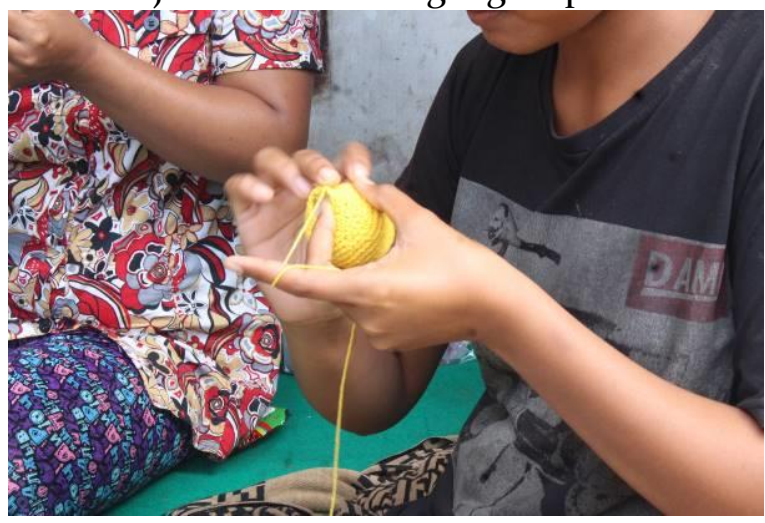

Gambar 3. Praktek Membuat Boneka Jari dari Benang Rajut

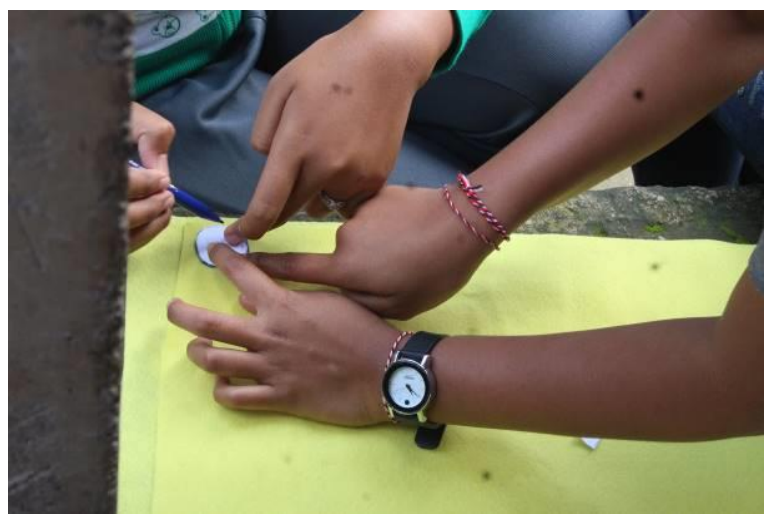

Gambar 4. Praktek Membuat Boneka Jari dari Bahan Flanel

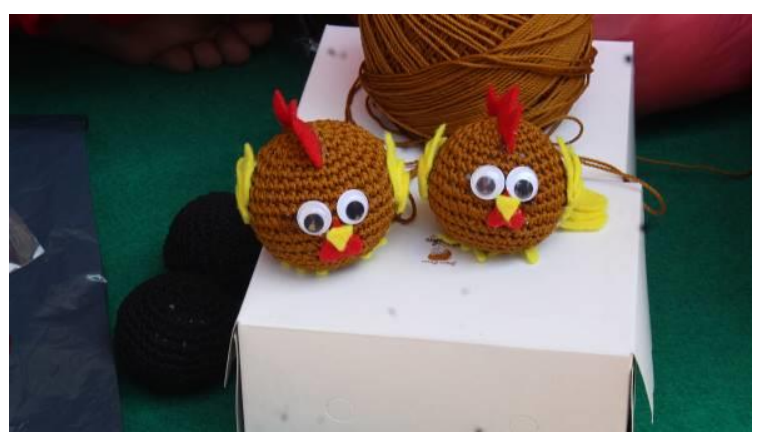

Gambar 5. Hasil Rajutan Boneka Jari 


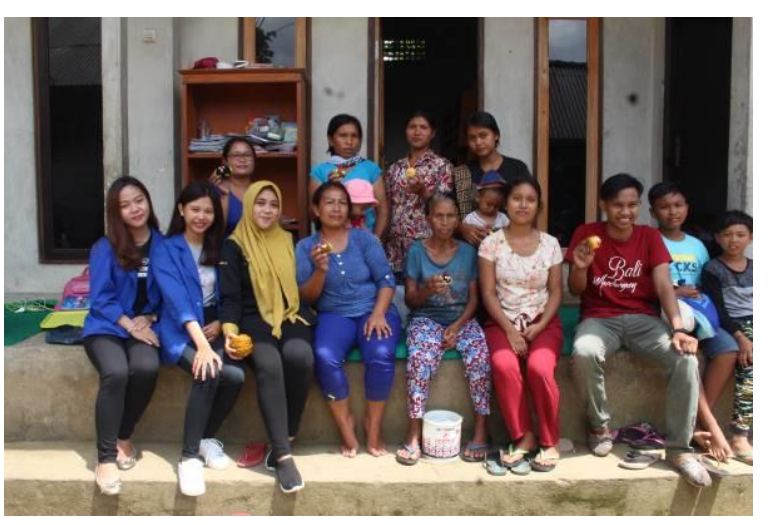

Gambar 6. Foto Bersama Kelompok Ibu Manukaya

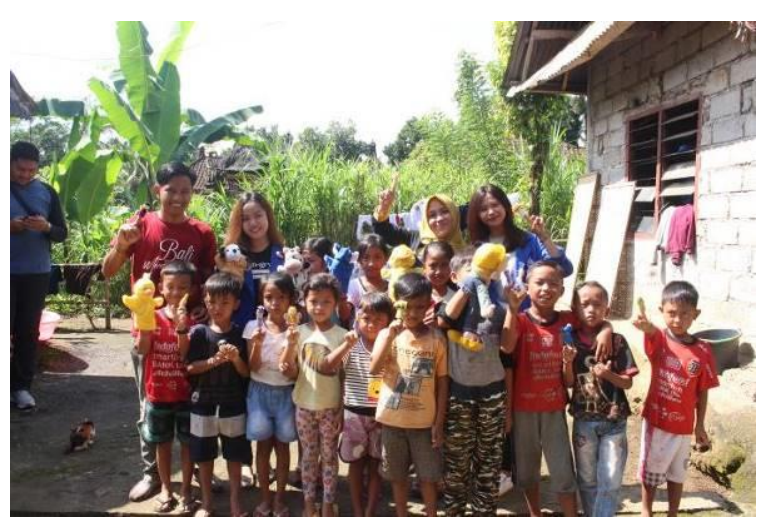

Gambar 7. Boneka Jari untuk anak-anak Desa Manukaya

\section{Tinjauan Revitalisasi Kearifan Lokal}

Kehidupan manusia pada dasarnya menurut Arifin (2009) tidak hanya memerlukan modal ekonomi akan tetapi juga memerlukan modal sosial, modal spiritual. Modal sosial dan spiritual ini tidak terbentuk barang (ekonomi). Fukuyama (2001) mengatakan bahwa modal sosial merupakan seperangkat norma atau nilai secara informal yang dimiliki secara bersama oleh individu maupun kelompok dimana mereka bisa saling berintegrasi satu sama lain. Pada sekelompok masyarakat norma informal dijadikan sebagai acuan atau pandangan untuk menjalin kerja sama dan berinteraksi meskipun memiliki perbedaan yang bisa disebut sebagai kearifan lokal. Kearifan lokal dalam tatanan budaya memiliki nilai kebaikan dan menjadi acuan dalam tindakan kehidupan masyarakat prinsip tersebut menjadi pola pikir dan tradisi kehidupan setempat. Dongeng merupakan salah satu tradisi yang telah ada pada saat zaman dulu. Tradisi mendongeng ini yang harusnya dihidupkan kembali agar anak-anak muda sekarang bisa tetap menjalankan sebagai agen perubahan namun tetap mempertahankan kearifan lokal salah satunya dengan mendongeng. Tumbuh kembang anak tidak bisa terlepas dari peran ibu dalam kehidupan sehari-hari. Studi literature tentang perkembangan anak dipengaruhi oleh seorang ibu, dibuktikan oleh Maulina, Makhfudli, \& Ulfiana (2014) adalah Ibu yang tidak bekerja bisa mendidik anak secara maksimal dengan cara yang beragam dikarenakan estimasi waktu yang diperlukan lebih panjang daripada ibu yang bekerja. Melihat kelompok ibuibu rumah tangga di Desa Manukaya mayoritas aktivitas berada di rumah maka akan menjadi tepat sasaran jika diberikan pendidikan secara informal tentang keafrifan lokal melalui mereka dengan cara mendongeng.

\section{SIMPULAN}

Berdasarkan kegiatan tersebut pada kelompok ibu-ibu rumah tangga Desa Manukaya dapat diambil kesimpulan bahwa pemberian edukasi tentang kearifan lokal, stretegi mempertahankan kearifan lokal salah satunya dengan cara mendongeng serta pelatihan pembuatan boneka jari dengan melihat potensi kelompok ibu-ibu disana yakni merajut berjalan dengan lancar. Hasil kegiatan yang pertama adalah peserta (ibu-ibu rumah tangga Desa Manukaya) mengalami peningkatan pemahaman tentang pentingnya kearifan lokal sebagai salah satu cara mempertahankan identitas bangsa Indonesia khususnya Bali. Kedua, adanya peningkatan pengetahuan dan pemahaman tentang bagaimana menjaga kearifan lokal Bali dengan cara mendongeng. Strategi dan tips yang diberikan kepada kelompok ibu-ibu rumah tangga Desa Manukaya ini juga dipraktekkan kepada anak-anak yang ada di sana. Ketiga, dengan potensi yang dimiliki oleh ibu-ibu disana dapat meningkatkan literasi melalui mendongeng dengan cara media boneka jari bisa diteruskan dan bahkan dipasarkan pada wisatawan asing yang berkunjung kesana sesuai dengan satu paket perangkat aktor dari cerita dongeng Bali. 
JPPM (Jurnal Pendidikan dan Pemberdayaan Masyarakat), 6 (1), 2019 - 49

Riza Wulandari, I Wayan Gede Lamopia

\section{DAFTAR PUSTAKA}

Adisasmita, R. (2006). Pembangunan pedesaan dan perkotaan. Yogyakarta: Graha Ilmu.

Antosa, Z. (2014). Pendekatan kearifan lokal untuk meningkatkan kemampuan apresiasi seni mahasiswa pendidikan Guru Sekolah Dasar Fkip Universitas Riau. Primary: Jurnal Pendidikan Guru Sekolah Dasar, 3(2), 85-96.

Arifin, S. (2009). Studi agama: perspektif sosiologis dan isu-isu kontemporer. Malang: UMM Press.

Fukuyama, F. (2001). Social capital, civil society and development. Third World Quarterly, 22(1), 7-20.

Kurmia, N. (2005). Perkembangan teknologi komunikasi dan media baru: implikasi terhadap teori komunikasi. Mediator: Jurnal Komunikasi, 6(2), 291-296.

Maulina, E. I., Makhfudli, M., \& Ulfiana, E. (2014). Perbedaan peran ibu dalam stimulasi perkembangan anak usia prasekolah pada ibu bekerja dan tidak bekerja di wilayah kerja Puskesmas Banyu Urip Surabaya. Indonesian Journal of Community Health Nursing, 3(1), 52-56.

Ramadhan, A. (2015). Disfungsional peran karang taruna dalam pelestarian kearifan lokal di Kampung Cireundeu.
SOSIETAS, 6(2). Retrived from http://ejournal.upi.edu/index.php/sosi etas/article/view/4107

Saddhono, K. (2016). Dialektika Islam dalam mantra sebagai bentuk kearifan lokal Budaya Jawa. AKADEMIKA: Jurnal Pemikiran Islam, 21(1), 83-98.

Sibarani, R. (2012). Kearifan lokal: hakikat, peran, dan metode tradisi lisan. Jakarta: Asosiasi Tradisi Lisan (ATL).

Sulistiyani, A. T. (2004). Kemitraan dan model-model pemberdayaan. Yogyakarta: Gava Media.

Sutarman, U. (2017). Penerapan konsep kearifan lokal masyarakat sunda (sabilulungan) dalam pembelajaran sejarah. Historia: Jurnal Pendidik dan Peneliti Sejarah, 1(1), 33-36.

Suyatno, H. (2003). Pengembangan masyarakat: dari pembangunan sampai pemberdayaan. Yogyakarta: Aditya Media.

Utomo, S. B. (2013). Mendongeng dalam perspektif pendidikan. Agastya: Jurnal Sejarah dan Pembelajarannya, 3(01).

Wibowo, A., \& Gunawan. (2015). Pendidikan karakter berbasis kearifan lokal di sekolah: konsep, strategi, dan implementasi. Yogyakarta: Pustaka Pelajar. 